\title{
Human Resource Management in the Construction Industry - Sustainability Competencies
}

Renard Yung Jhien Siew, (The University of New South Wales, Australia)

\begin{abstract}
While environmental sustainability has been the subject of much debate in the last decade, it was not until recently that attention started to shift towards human resource management as an enabler for sustainability. Yet, this is still a relatively under researched area. Much is still unknown about the role of an individual worker in contributing towards sustainable development. This paper addresses the gap by proposing a framework to measure sustainability competencies of employees within the construction industry sector. As part of the framework, four proficiency levels together with relevant descriptions are defined for a total of eight sustainability competencies. Suggested proficiency levels are then mapped to main construction related jobs based on the framework. An example is also given to illustrate the manner in which competencies should be assessed. This framework is original and of practical use to construction managers and human resource practitioners.
\end{abstract}

Keywords: Sustainability competencies, Human resource management, Construction

\section{Introduction}

There is a lot of ongoing discussion about environmental sustainability particularly since the aftermath of the Kyoto Protocol. Governments worldwide have taken measures to address these issues through global forums and conferences, deliberating on ways to reduce carbon emissions. It is obvious even to the most casual observer that environmental issues tend to dominate the discussion at a socio-political level with very little focus at an individual level. Dahl (2012, p. 17), however, stresses the importance of individual roles in attaining sustainability goals, claiming that 'what happens to the planet is the cumulative result of over 6 billion independent producing and consuming individuals'.

Spooner and Kaine (2010) maintain that traditionally, the focus on human resource management (HRM) is largely around aspects of task domains of the employment relationship such as recruitment, remuneration, employment conditions, training and development. More recently, there is a move towards the recognition of HRM as an enabler to achieve sustainability goals. For example, Wirtenberg et al. (2007) and Harmon et al. (2010) have illustrated the big picture of how HRM can play a role in sustainability management. They highlight that the critical goal for HRM in the next few years is the development of competencies, collaborative strategies and organisational capabilities to support an organisation's sustainability journey'. Wilkinson et al. (2001) discuss the role of human resources in achieving corporate and environmental sustainability. Dunphy and Griffiths (1998) claim that there are commonalities between human and ecological sustainability and both are to a certain extent interdependent.

None of the literature identified tackles the issue of how HRM might be used to build sustainability capabilities. This is especially lacking in the construction industry sector which is well-known for its '3D' image (dirty, difficult, dangerous). According to the Centre for International Economics Canberra and Sydney (2007), 23\% of Australia's total greenhouse gas emissions actually come from the energy demand in the construction sector. The breakdown of prominent contributors of emissions within construction are the cement industry (20\%), chemicals and petrochemicals (17\%), iron and steel industry (16\%) and 
aluminium/ non-ferrous metals (5\%). The CRC Construction Innovation has also highlighted common barriers within the construction industry in Australia such as poor industry image, low levels of education in information and communication of technologies and management, poor employer-employee relations, procurement structures that promote adversarial site relationships and disparate occupational health and safety (OHS) legislation and guidelines across different states (CRC, 2004).

Against this background, it is vital that sustainability capabilities are developed within the construction industry. This paper addresses the gap by proposing a sustainability competency framework applicable to this industry. Project owners, construction managers and HR practitioners would find the proposed framework useful.

\section{Background}

First, some relevant concepts relating to HRM, for example, recruitment and performance management are given in this section. This is followed by an explanation of the link between competency as well as both the recruitment and performance management processes to set the context for the subsequent sections.

\section{Recruitment and Selection}

Recruitment is defined as a process of bringing in the right people who have the potential of making a positive contribution to a particular organisation regardless of whether it is for short term or long term (Bratton and Gold, 2003). Recruitment can be stimulated by the following reasons:

- An employee decides to leave a company due to retirement or better job offer

- Organisational expansion which requires immediate work force

- Changes in global environment requiring different skilled employees

Recruitment can be done either internally or externally. Internal recruitment involves hiring from within an organisation and could have potential benefits. Apart from significant savings from the cost of advertising, it can also act as a source of motivation to the employees who are able to see opportunities for career progression within the company. However, the downside of this is letting go of the opportunity of bringing new experiences and diversity to the organisation (Newell and Shackleton, 2002).

\section{Performance Management}

Performance management has always been a highly debated issue (Storey, 1992). One reason is because of the lack of agreement about its definition. What exactly constitutes performance management? Storey (1992) proposed that performance management 'refers to any designed activity related to the performance of employees', claiming that it was similar to performance -related pay (PRP). Bevan and Thompson (1992) claim that a performance management system includes the following characteristics: clear communication of goals to employee, conducting formal reviews of progress; using the reviews to establish training requirements.

A more recent literature defined performance management as merely a process of assessing an employee's progress towards achieving a company's goals and is perceived as a useful tool in determining rewards and penalties (Loosemore et al., 2003). Performance management had received many criticisms since its proposal. Despite its usefulness, McGregor (1960) criticized its value claiming that it is demotivating and creates a judgmental setting. Even Deming (1982) the quality expert, raised his concern calling appraisal a 'deadly disease' as it opens up a doorway to blame employees for systematic problems which arise in an organisation. Hence, performance appraisal has always been deemed to be the least popular of all the other activities in HRM. Yet, its significance cannot 
be refuted or diminished for indeed the failure to show any evidence of management control would indicate ineffectiveness (Bratton and Gold, 2003). Lately, the focus of organisations in integrating human resource management together with its business strategies has resulted in companies perceiving performance management as a form of systematic approach towards performance management (Loosemore et al., 2003).

Among the many advantages of performance management which have been identified by Bratton and Gold (2003) are:

- Boost morale and levels of motivation

- Help identify suitable candidates for promotion

- Aid in the setting of organisational goals

- Identify areas which require training and development.

\section{Linking Competencies with the Recruitment and Performance Management}

\section{Processes}

There is no doubt that competencies are very closely linked to both the recruitment and performance management processes. Four steps are detailed here for the reader. The first step typically involves reviewing the competency dictionary. The competency dictionary consists of descriptions of competency and the various proficiency levels (see Section 3). The second step involves the job design where proficiency or competency levels are selected by the manager or HR practitioner (depending on the requirements of a job). The selected proficiency levels are then used as a basis for guiding the recruitment process where suitable candidates are sourced. The third step involves assessing the performance of an incumbent. The performance of an incumbent (or holder of a particular job) is assessed based on how well they have achieved the required competency level. After the performance management process, gaps in competencies are identified in the fourth step. Gap is referred to as the difference between the actual proficiency level and the required proficiency level for any given competency.

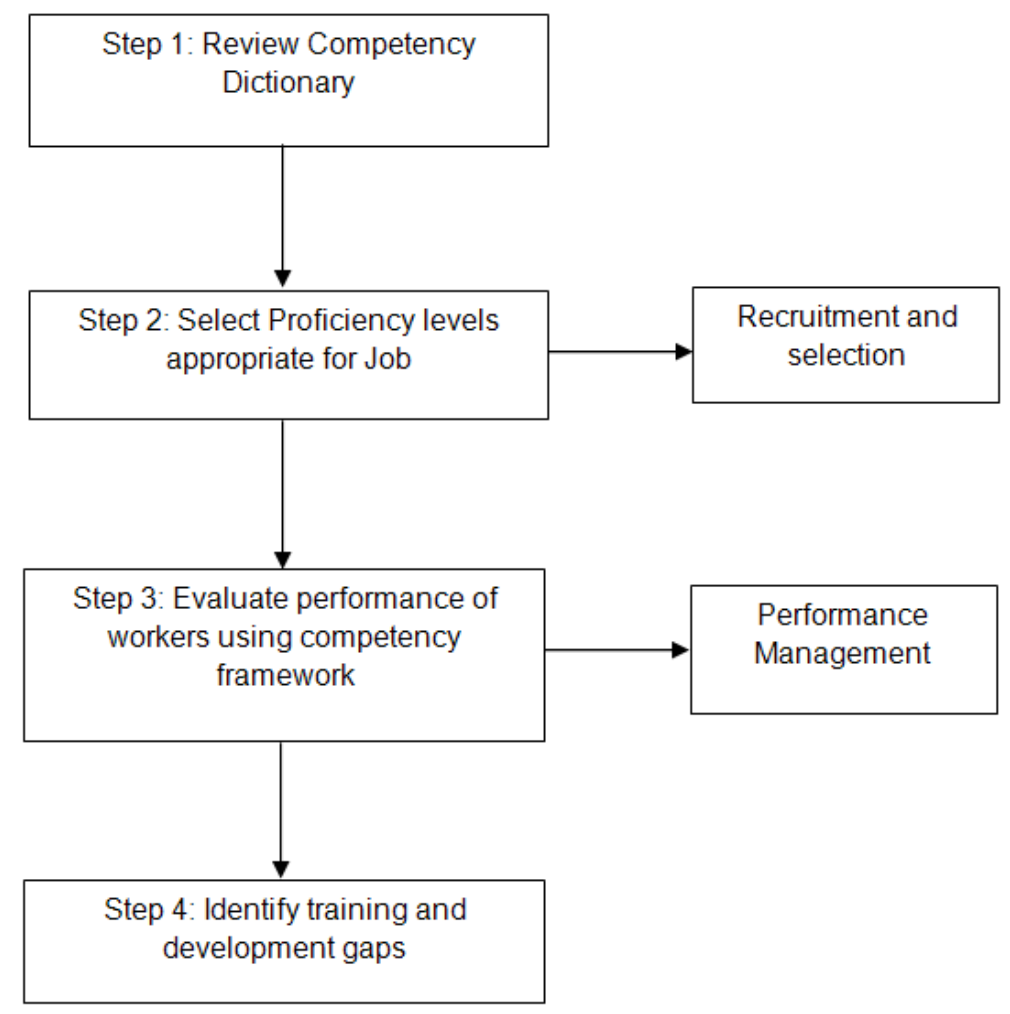

Figure 1 Steps involved in identifying training gaps for employees 


\section{Performance Management in Construction Companies}

It was reported that PRP is the most popular evaluation technique in the construction sector. PRP focuses wholly on output and process criteria and employees are rewarded based on the achievement of goals (Loosemore et al., 2003). According to Druker and White (1996), one of the major challenges in the construction industry is the capacity to perform efficient PRP systems partly because of the somewhat 'volatile' nature of the construction industry where employees are constantly rotated around different projects. To achieve this, a few methods such as competency-based or skills-based systems have been developed. The distinctive feature among all of them is the nature in which assessment is carried out. Some adopt a qualitative approach through the description of an employee's performance while others adopt a more quantitative approach via an employee performance rating scale.

Yet, to this end, there is hardly any proposal recommending sustainability competencies for employees within the construction industry. 'You can't manage what you don't measure'. Without sustainability competencies, there is simply no indication as to how employees are contributing or working towards the attainment of sustainability goals. The following section in this paper fills this gap accordingly.

\section{Competency Dictionary}

Although, the CRC Construction Innovation (Dingsdag et al., 2006) has published a construction safety competency framework, this is still inadequate. The competencies suggested as part of the framework take on a narrow view and focuses only on health and safety competencies instead of taking on a broader view of sustainability to also include environmental issues. In addition, there are no guidelines as to how these competencies should be measured. This paper addresses existing limitations by proposing a competency dictionary comprising of eight sustainability competencies together with detailed descriptions by proficiency levels.

The four proficiency levels used in the competency dictionary is broadly defined in this paper as follows:

P1: Demonstrates basic knowledge/understanding of subject matter

P2: Applies knowledge and analyses outcomes stemming from action

P3: Manages, develops action plans to mitigate negative impacts

P4: Provides advisory services and drives performance based on extensive experience.

Each of these eight sustainability competencies is also mapped to the competencies suggested by CRC Construction Innovation so that the readers can compare them directly (top right hand corner- see Appendix A for explanation of the safety management tasks (SMTs) and Dingsdag et al. (2006) for more detailed elaboration). 


\begin{tabular}{|c|c|c|c|}
\hline \multicolumn{3}{|c|}{ Competency 1: Safety auditing } & SMT 6 \\
\hline \multicolumn{4}{|c|}{$\begin{array}{l}\text { This competency refers to the knowledge and ability to conduct OHS audits or reviews including } \\
\text { understanding of OHS management systems, strategies and standards, applicable regulations. It } \\
\text { includes application of OHS strategies, processes and risk identification in the development of OHS } \\
\text { audit programmes. }\end{array}$} \\
\hline P1 & $\mathrm{P} 2$ & P3 & P4 \\
\hline $\begin{array}{l}\text { Demonstrates knowledge } \\
\text { of OHS management } \\
\text { systems, regulatory } \\
\text { requirements and their } \\
\text { applications. }\end{array}$ & $\begin{array}{l}\text { Evaluates application } \\
\text { of OHS strategies and } \\
\text { processes, identifies } \\
\text { risks and develops } \\
\text { relevant audit } \\
\text { programmes. }\end{array}$ & $\begin{array}{l}\text { Able to lead scoping, } \\
\text { performance, and } \\
\text { audit reviews on } \mathrm{OHS} \\
\text { areas. }\end{array}$ & $\begin{array}{l}\text { Able to provide advice } \\
\text { on OHS governance } \\
\text { including risk } \\
\text { management } \\
\text { framework based on } \\
\text { established standards } \\
\text { and practices. }\end{array}$ \\
\hline \multicolumn{4}{|c|}{ Activities relating to the proficiency levels } \\
\hline $\begin{array}{l}\text { - Understands OHS } \\
\text { Management System } \\
\text { Framework, strategies } \\
\text { and its } \\
\text { applications/impact to } \\
\text { the overall business } \\
\text { processes. } \\
\text { - Understands the OHS } \\
\text { regulatory requirements } \\
\text { and its application. } \\
\text { - Understands OHS } \\
\text { Standards which } \\
\text { includes industrial } \\
\text { codes of practices and } \\
\text { its application. } \\
\text { Understands the } \\
\text { organisations key OHS } \\
\text { risks and their impact on } \\
\text { the business and } \\
\text { processes. } \\
\text { Demonstrates an } \\
\text { understanding of the } \\
\text { importance of } \\
\text { maintaining a strategic } \\
\text { alliance. }\end{array}$ & $\begin{array}{l}\text { - Applies the OHS } \\
\text { Management } \\
\text { System and } \\
\text { Strategies to } \\
\text { review } \\
\text { assignments. } \\
\text { - Evaluates the } \\
\text { application of OHS } \\
\text { strategies and } \\
\text { processes to } \\
\text { ensure that } \\
\text { business objectives } \\
\text { are met. } \\
\text { Applies the OHS } \\
\text { regulatory } \\
\text { requirements and } \\
\text { standards to } \\
\text { engagements. } \\
\text { Analyses and } \\
\text { identifies key OHS } \\
\text { risks and develops } \\
\text { appropriate audit } \\
\text { programmes and } \\
\text { tests for immediate } \\
\text { superior's review } \\
\text { and approval. } \\
\text { Maintains a } \\
\text { strategic alliance } \\
\text { with the various } \\
\text { stakeholders under } \\
\text { direction of seniors. }\end{array}$ & $\begin{array}{l}\text { - Aligns OHS plan to } \\
\text { include OHS } \\
\text { business strategies. } \\
\text { - Leads in scoping of } \\
\text { OHS reviews based } \\
\text { on the knowledge of } \\
\text { business, strategy } \\
\text { and processes. } \\
\text { - Leads performance } \\
\text { reviews and reviews } \\
\text { of compliance to } \\
\text { legal framework and } \\
\text { standards/codes of } \\
\text { practices. } \\
\text { Provides } \\
\text { recommendations } \\
\text { on the } \\
\text { implementation of } \\
\text { the OHS risk } \\
\text { management } \\
\text { strategy including } \\
\text { their impact on } \\
\text { business and } \\
\text { processes. } \\
\text { Coaches on } \\
\text { appropriate } \\
\text { problem-solving } \\
\text { techniques to } \\
\text { address risks and } \\
\text { improve controls. } \\
\text { Develops, nurtures } \\
\text { and maintains a } \\
\text { strategic alliance } \\
\text { with the various } \\
\text { stakeholders. } \\
\text { - }\end{array}$ & $\begin{array}{l}\text { Generates value- } \\
\text { added } \\
\text { recommendations } \\
\text { to increase OHS } \\
\text { contribution to } \\
\text { business } \\
\text { opportunities, } \\
\text { efficiency (cost } \\
\text { optimisation), risk } \\
\text { reduction and } \\
\text { effectiveness. } \\
\text { Benchmarks } \\
\text { against emerging } \\
\text { OHS best practices } \\
\text { (strategies). } \\
\text { Creates } \\
\text { understanding for } \\
\text { the need of } \\
\text { effective internal } \\
\text { control strategies } \\
\text { and application of } \\
\text { OHS best } \\
\text { practices. } \\
\text { Provides advice to } \\
\text { enhance the OHS } \\
\text { risk management } \\
\text { framework to } \\
\text { adequately identify } \\
\text { and address } \\
\text { potential or } \\
\text { emerging OHS } \\
\text { risks and } \\
\text { correlation with the } \\
\text { business } \\
\text { processes. }\end{array}$ \\
\hline
\end{tabular}

Table 1 Safety auditing

Siew, R Y J (2014) 'Human resource management in the construction industry - Sustainability competencies', Australasian Journal of Construction Economics and Building, 14 (2) 87-103 


\section{Competency 2: Managing environmental aspects, impacts and OHS hazards}

This competency is about the ability to identify, assess, eliminate and mitigate significant environmental impacts and OHS hazards.

\begin{tabular}{|c|c|c|c|}
\hline P1 & P2 & P3 & P4 \\
\hline $\begin{array}{l}\text { Demonstrates the ability to } \\
\text { conduct environmental } \\
\text { impact/ OHS hazard } \\
\text { identification and risk } \\
\text { assessment with } \\
\text { guidance. }\end{array}$ & $\begin{array}{l}\text { Conducts and } \\
\text { validates } \\
\text { environmental impact/ } \\
\text { OHS hazard } \\
\text { identification and risk } \\
\text { assessment. }\end{array}$ & $\begin{array}{l}\text { Manages and guides } \\
\text { team in identification, } \\
\text { risk assessment and } \\
\text { mitigation measures } \\
\text { concerning } \\
\text { environmental impact/ } \\
\text { OHD hazards. }\end{array}$ & $\begin{array}{l}\text { Advises on } \\
\text { identification } \\
\text { assessment and } \\
\text { mitigation of } \\
\text { environmental } \\
\text { impact/ OHS hazard. }\end{array}$ \\
\hline
\end{tabular}

Activities relating to the proficiency levels

- Demonstrates understanding and ability to conduct environmental aspect, environmental impact or OHS hazard identification and risk assessment with supervision.

- Identifies and proposes mitigation measures for significant environmental aspects, environmental impacts or OHS risks.
- Validates environment aspects, environmental impacts or hazards.

- Identifies Environmental aspects and impacts / OHS hazards independently.

- Conducts and validates environmental aspect, environmental impact or OHS risk assessment.

- Reviews effectiveness of proposed mitigation measures for significant environmental aspects, environmental impacts or OHS risks.
- Manages and leads environmental aspect, environmental impact or OHS hazard identification, assessment, gap analysis and prioritisation initiatives.

- Coaches team in all matters relating to OHS environmental aspects, environmental impacts or OHS risks.
- Advises on environmental aspect, environmental impact or OHS hazard identification tools.

- Advises on improvements to environmental aspects-impacts / $\mathrm{OHS}$ risks assessment.

- Strategise and prioritise the implementation of mitigation measures for significant environmental aspects, environmental impacts or OHS Risks.

Table 2 Managing environmental aspects, impacts and OHS hazards 


\section{Competency 3: Project Risk Management}

SMT 1

This competency focuses on the ability to ensure that project risks are identified and analysed and that appropriate responses are planned, monitored and controlled. Project risk management is a structured process that allows individual risk events and overall project risk to be understood and managed proactively, optimising success by minimising threats and maximising opportunities.

\begin{tabular}{|l|l|l|l|}
\hline \multicolumn{1}{|c|}{ P1 } & \multicolumn{1}{c|}{ P2 } & \multicolumn{1}{c|}{ P3 } & \multicolumn{1}{c|}{ P4 } \\
\hline $\begin{array}{l}\text { Learns to apply risk } \\
\text { management tools to } \\
\text { identify project risks. }\end{array}$ & $\begin{array}{l}\text { Analyses and update } \\
\text { risk register with } \\
\text { response plan to } \\
\text { resolve low impact } \\
\text { risks. }\end{array}$ & $\begin{array}{l}\text { Develops and } \\
\text { integrates risk } \\
\text { management plan with } \\
\text { appropriate tools and } \\
\text { template to track } \\
\text { potential risks. }\end{array}$ & $\begin{array}{l}\text { Advises project team } \\
\text { on proactive risk } \\
\text { management plan } \\
\text { that is in line with } \\
\text { organisational policies } \\
\text { and procedures to } \\
\text { ensure project } \\
\text { success. }\end{array}$ \\
\hline
\end{tabular}

Activities relating to the proficiency levels

- Learns to apply information-gathering techniques for collecting input during risk identification process such as brainstorming, SWOT analysis and interviewing skills.

- Learns quantitative and qualitative risk analysis techniques.

- Performs quantitative and qualitative risk analysis based on prescribed guidelines.

- Monitors and reports risks for assigned tasks.
- Participates to document and update risk register containing identified risks, risk analysis findings, and their respective Risk Response Plans.

- Assists to conduct quantitative and qualitative risk analysis.

- Monitors risks against Risk Management Plan for assigned activities.

- Assists to resolve low impact risks by following Risk Management Plan.
- Develops Risk Management Plan (including Risk Breakdown Structure) based on Project Scope Statement and Project Management Plan, taking into account environmental factors and process assets of the organisation, size, complexity, and importance of the project.

- Manages project team in developing and updating a Risk Register summarising potential risks, risk trigger events, and how to manage risks when they occur.

- Develops tools and templates to track, review and reevaluate the identified risks to verify whether it has happened.

- Integrates proactively measures for triggers to indicate the presence of an existing or new risk.
- Advises on Risk Management Plan and ensure that Risk Management Plan is in line with organisational policies and procedures.

- Champions periodical reviews of risk register and advises contingency plan if top priority risk happens.

- Leads project team in performing qualitative and quantitative risk analysis to assess probability of risk occurring and their respective impact.

- Advises project team on potential risks that could happen based on risks assessment reports.

Table 3 Project risk management

Siew, R Y J (2014) 'Human resource management in the construction industry - Sustainability competencies', Australasian Journal of Construction Economics and Building, 14 (2) 87-103 


\section{Competency 4: Safety recognition and reward}

SMT 20

This competency refers to the ability to provide recognition and reward to enhance safety performance. Identify individual strengths and development needs and ensures that reward does not encourage hiding or under reporting of incidents/ near misses.

\begin{tabular}{|c|c|c|c|}
\hline P1 & P2 & P3 & P4 \\
\hline $\begin{array}{l}\text { Have a basic safety level } \\
\text { of awareness. Provides } \\
\text { suggestions for rewarding } \\
\text { routine tasks. }\end{array}$ & $\begin{array}{l}\text { Provides others } \\
\text { opportunities for on- } \\
\text { the-job training, } \\
\text { assesses group } \\
\text { training needs. } \\
\text { Provides relevant } \\
\text { feedback on safety } \\
\text { work procedures. }\end{array}$ & $\begin{array}{l}\text { Determines training } \\
\text { opportunities and } \\
\text { provides formal and } \\
\text { informal safety } \\
\text { performance } \\
\text { feedback. Empowers } \\
\text { group towards } \\
\text { attainment of } \\
\text { safety/environmental } \\
\text { goals. }\end{array}$ & $\begin{array}{l}\text { Develops workforce } \\
\text { safety acumen and } \\
\text { steer resources to } \\
\text { support safety } \\
\text { development efforts/ } \\
\text { honest reporting. }\end{array}$ \\
\hline
\end{tabular}

Activities relating to the proficiency levels

- Describes the safety standard that must be delivered.

- Aware of safety training activities available for staff.

- Takes time to clearly respond to questions when asked.

- Prepares job aids to support on-the-job training.

- Provides informal feedback and support to others.

- Makes safety information available to others on a timely basis.

\section{- Assigns work} tasks/projects based on employee's capability taking into account safety issues.

- Allocates time to work with team members to define safety goals.

- Provides constructive feedback on safety work procedures.

- Provides practical advice and guidance on how things could be achieved.
- Readily identifies safety training or developmental needs.

- Takes on a role of a mentor.

- Initiates dialogue with unit/department employees to develop safety learning plans.

- Conducts reviews and debriefings so that individuals learn from past experiences

- Highlights that worker's compensation processes reflect the concern the company has for health and wellbeing of employees
- Identifies training needs on the basis of safety skills / knowledge required.

- Advocates for measures and safety reward systems based on project team performance.

- Delegates significantly complex assignments and create opportunities for safety development and learning.

- Ensures that reward does not encourage over reporting of positive performance indicators

- Ensures that reward does not encourage hiding or under reporting of incidents.

Table 4 Safety recognition and reward 


\begin{tabular}{|c|c|c|c|}
\hline \multicolumn{3}{|c|}{ Competency 5: Safety/ environmental reporting } & SMT 25 \\
\hline \multicolumn{4}{|c|}{$\begin{array}{l}\text { This competency refers to understanding of the OHS/environmental processes and procedures } \\
\text { related to reporting requirements. }\end{array}$} \\
\hline $\mathrm{P} 1$ & $\mathrm{P} 2$ & P3 & P4 \\
\hline $\begin{array}{l}\text { Demonstrates } \\
\text { understanding of } \\
\text { environmental/safety } \\
\text { standard reporting } \\
\text { requirements and able to } \\
\text { generate standard reports. }\end{array}$ & $\begin{array}{l}\text { Able to analyse } \\
\text { customer reporting } \\
\text { requirements and } \\
\text { generate ad-hoc } \\
\text { reports. }\end{array}$ & $\begin{array}{l}\text { Analyses reporting } \\
\text { requirements, and } \\
\text { able to provide } \\
\text { recommendations for } \\
\text { improving report } \\
\text { generation. }\end{array}$ & $\begin{array}{l}\text { Able to evaluate } \\
\text { areas of weaknesses } \\
\text { and drives } \\
\text { improvements. }\end{array}$ \\
\hline \multicolumn{4}{|c|}{ Activities relating to the proficiency levels } \\
\hline $\begin{array}{l}\text { - Understands basic } \\
\text { standard offerings of } \\
\text { reporting for customers. } \\
\text { - Able to generate reports } \\
\text { based on Standard } \\
\text { Operating Procedures } \\
\text { and schedule. } \\
\text { - Ability to obtain } \\
\text { appropriate data or } \\
\text { information }\end{array}$ & $\begin{array}{l}\text { - Performs simple } \\
\text { analysis of } \\
\text { customer reporting } \\
\text { requirements. } \\
\text { - Able to perform ad- } \\
\text { hoc reporting } \\
\text { activities without } \\
\text { supervision. } \\
\text { - Ability to analyse } \\
\text { data }\end{array}$ & $\begin{array}{l}\text { Performs complex } \\
\text { analysis of safety } \\
\text { reporting } \\
\text { requirements. } \\
\text { - Provides } \\
\text { recommendations } \\
\text { for improving } \\
\text { process of reporting } \\
\text { to both } \\
\text { management and } \\
\text { employees } \\
\text { Consults with and } \\
\text { counsels } \\
\text { employees and } \\
\text { liases with } \\
\text { management }\end{array}$ & $\begin{array}{l}\text { - Implements and } \\
\text { drives } \\
\text { improvements to } \\
\text { safety reporting } \\
\text { - Seeks commitment } \\
\text { to process from } \\
\text { management/ } \\
\text { workforces/ } \\
\text { contractors and } \\
\text { subcontractors } \\
\text { - Regularly } \\
\text { communicates } \\
\text { conclusions/ } \\
\text { results to all } \\
\text { relevant parties }\end{array}$ \\
\hline
\end{tabular}

Table 5 Safety/ environmental reporting 


\section{Competency 6: Monitoring contractors/subcontractors}

SMT 26

This competency refers to the ability to monitor contractors/subcontractors to ensure that all parties are performing up to the standard required by legislation (i.e. environmental or health and safety).

\begin{tabular}{|c|c|c|c|}
\hline P1 & P2 & P3 & P4 \\
\hline $\begin{array}{l}\text { Demonstrates the basic } \\
\text { ability to understand } \\
\text { roles of different parties } \\
\text { involved. }\end{array}$ & $\begin{array}{l}\text { Analyses and } \\
\text { communicates } \\
\text { issues which could } \\
\text { pose } \\
\text { safety/environmental } \\
\text { hazards to projects. }\end{array}$ & $\begin{array}{l}\text { Develops } \\
\text { recommendation to } \\
\text { ensure that } \\
\text { safety/environmental } \\
\text { performance are on } \\
\text { track. }\end{array}$ & $\begin{array}{l}\text { Drives safety/ } \\
\text { environmental } \\
\text { performance in all } \\
\text { aspects of work. }\end{array}$ \\
\hline
\end{tabular}

Activities relating to the proficiency levels

- Understands the roles played by different parties.

- Have an awareness of $\mathrm{OH} \& \mathrm{~S}$ issues and legal requirements relating to specific duty of care of all parties

\section{- Able to have} meaningful regular communication/ discussion with sub contractors on safety performance praising outcomes that have met or exceeded projected outcomes

- Have meaningful communication/ discussion with subcontractors on safety performance outcomes that have not met projected outcomes and negotiation of appropriate remedial action by subcontractor

- Regular examination of incident notifications/ injury/first-aid register that proactively identifies hazards
- Able to develop safety management system manual/ documents that relates directly to an organisation's $\mathrm{OH} \& \mathrm{~S}$ values, policy and procedure

- Develops basic audit tools that compares projected stated performance standards of subcontractors dependent on the length of contractor engagement.
- Implements and drives safe work methods for key construction activities and organisation's safety/ environmental management systems

- Seeks commitment to process from management/ workforces/ contractors and subcontractors

- Consistent clarification of required behaviour to contractors and subcontractors

Table 6 Monitoring contractors/subcontractors 


\section{Competency 7: Communication}

SMT 13,18

This competency refers to the ability to organise and convey OHS/environmental information, views and concepts in a concise and clear manner for a variety of audiences. It involves adopting the appropriate communication approaches to converse and influence others in selecting the best course of action to achieve desired results.

\begin{tabular}{|c|c|c|c|}
\hline P1 & P2 & P3 & P4 \\
\hline $\begin{array}{l}\text { Demonstrates knowledge } \\
\text { and understanding of } \\
\text { fundamental } \\
\text { communication principles. }\end{array}$ & $\begin{array}{l}\text { Clearly conveys ideas } \\
\text { and information to } \\
\text { engage audiences } \\
\text { and help them retain } \\
\text { the message. Uses } \\
\text { appropriate methods } \\
\text { to collect, compile } \\
\text { and distribute } \\
\text { information. }\end{array}$ & $\begin{array}{l}\text { Develops } \\
\text { communication } \\
\text { strategies in order to } \\
\text { adopt appropriate } \\
\text { styles and channels of } \\
\text { communication for } \\
\text { different groups. } \\
\text { Interprets information } \\
\text { and responds } \\
\text { appropriately. }\end{array}$ & $\begin{array}{l}\text { Articulates ideas and } \\
\text { perspectives with } \\
\text { clarity. Advises on } \\
\text { communication } \\
\text { strategies and } \\
\text { promotes continuous } \\
\text { improvements of } \\
\text { organisational } \\
\text { communication. }\end{array}$ \\
\hline
\end{tabular}

Activities relating to the proficiency levels

- Builds in depth knowledge of nature of projects.

- Demonstrates an understanding of project communication strategy and where they fit in.

- Writes clearly, concisely and accurately in plain English all formats.

- Respond to questions with accurate and complete answers in a logical manner.

- Use terminology appropriate for the audience.
- Able to identify and understand internal and external audience's needs and adapts communication style accordingly.

- Aware of the organisation's key priorities.

- Understanding key relationships and the importance of networks for the organisation's communications.

- Uses appropriate methods to collect, compile and distribute information.

- Demonstrates the ability to make effective safety toolbox presentations.
- Adopts appropriate styles and channels of communication for diverse groups.

- Able to use persuasion to influence and convey messages clearly and logically.

- Ensures ideas and perspectives are coherently related to situational needs.

- Identifies communication problems and initiates process improvements

- Develop and implement new and/or improved methods of verbal and written communication for the team.
- Champions communication skills and uses persuasion to gain commitment.

- Promotes continuous improvement of organisational communication.

- Demonstrate flexibility in achieving mutually agreeable solutions.

- Coach others on communication concepts, approaches and problem resolution.

- Develop communication strategies in order to present issues with clarity and influences others.

- Challenges unsafe behaviour/ attitude at any level

Table 7 Communication

Siew, R Y J (2014) 'Human resource management in the construction industry - Sustainability competencies', Australasian Journal of Construction Economics and Building, 14 (2) 87-103 


\begin{tabular}{|c|c|c|c|}
\hline \multicolumn{3}{|c|}{$\begin{array}{l}\text { Competency 8: OHS regulatory and management system/ } \\
\text { Planning and assessment }\end{array}$} & SMT 29 \\
\hline \multicolumn{4}{|c|}{$\begin{array}{l}\text { This competency focuses on the ability to assess the OHS regulatory and management systems and } \\
\text { prioritise action plans to solve operational gaps. }\end{array}$} \\
\hline P1 & $\mathrm{P} 2$ & P3 & P4 \\
\hline $\begin{array}{l}\text { Demonstrates } \\
\text { knowledge and } \\
\text { understanding of } \\
\text { OHS regulatory and } \\
\text { management } \\
\text { system. }\end{array}$ & $\begin{array}{l}\text { Coordinates and } \\
\text { executes OHS } \\
\text { assessments, } \\
\text { conducts gap analysis } \\
\text { and prioritise action } \\
\text { plans. }\end{array}$ & $\begin{array}{l}\text { Manages OHS } \\
\text { assessments and } \\
\text { recommends possible } \\
\text { solutions for gap } \\
\text { resolution. }\end{array}$ & $\begin{array}{l}\text { Provides expertise on OHS } \\
\text { regulatory and management } \\
\text { system requirements, gap } \\
\text { analysis and prioritisation. }\end{array}$ \\
\hline \multicolumn{4}{|c|}{ Activities relating to the proficiency levels } \\
\hline $\begin{array}{l}\text { - Understands } \\
\text { fundamental OHS } \\
\text { regulatory and } \\
\text { management } \\
\text { system } \\
\text { requirements. } \\
\text { - Conducts OHS } \\
\text { regulatory and } \\
\text { management } \\
\text { system gaps } \\
\text { analysis and } \\
\text { prioritisation with } \\
\text { guidance. }\end{array}$ & $\begin{array}{l}\text { - Plans OHS } \\
\text { assessments } \\
\text { based on the } \\
\text { regulatory and } \\
\text { management } \\
\text { system } \\
\text { requirements. } \\
\text { - Conducts OHS } \\
\text { regulatory and } \\
\text { management } \\
\text { system } \\
\text { assessment, gap } \\
\text { analysis and } \\
\text { prioritisation } \\
\text { independently. } \\
\text { Recommends } \\
\text { solutions to } \\
\text { address gaps in } \\
\text { the OHS regulatory } \\
\text { \& management } \\
\text { system. }\end{array}$ & $\begin{array}{l}\text { Manages the OHS } \\
\text { regulatory and } \\
\text { management } \\
\text { system gaps } \\
\text { analysis and } \\
\text { prioritisation. } \\
\text { - Guides the team on } \\
\text { OHS regulatory \& } \\
\text { management } \\
\text { system } \\
\text { requirements, gap } \\
\text { analysis and } \\
\text { prioritisation. } \\
\text { Validates } \\
\text { recommendations } \\
\text { to address gaps in } \\
\text { the OHS regulatory } \\
\text { management } \\
\text { system. } \\
\text { Develops suitable } \\
\text { implementation } \\
\text { plans for gaps } \\
\text { resolution. }\end{array}$ & $\begin{array}{l}\text { - Acts as a subject matter } \\
\text { expert on OHS regulatory } \\
\text { and management system } \\
\text { requirements, gap } \\
\text { analysis and prioritisation. } \\
\text { - Advises the } \\
\text { Group/division/business } \\
\text { unit on relevant OHS } \\
\text { regulatory and } \\
\text { management system } \\
\text { matters. } \\
\text { Ensures implementation } \\
\text { plans for OHS regulatory } \\
\text { and management system } \\
\text { gaps resolution are } \\
\text { aligned to the business } \\
\text { objectives. }\end{array}$ \\
\hline
\end{tabular}

Table 8 OHS regulatory and management system/ planning and assessment

\section{Mapping Proficiency Levels}

The sustainability competency dictionary developed in section 3 was then shared with a working group of 24 construction practitioners. These practitioners had at least 5 years of working experience in the construction industry. They were asked collectively as a group to map the proficiency levels (for the eight sustainability competencies) of 11 jobs related to the construction industry - CEO of a construction company, senior manager of a construction company, construction manager, project manager, engineer, site manager, ESH advisor, regional safety manager, state safety manager, national safety manager and site workers as suggested by Dingsdag et al. (2006). The final result from the mapping exercise is shown in Table 9. 


\begin{tabular}{|c|c|c|c|c|c|c|c|c|c|c|c|c|}
\hline No. & Construction Sustainability Competencies & 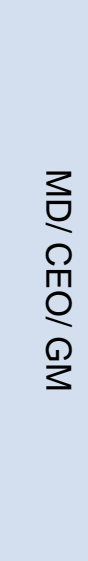 & 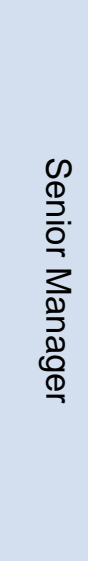 & 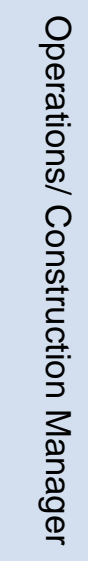 & 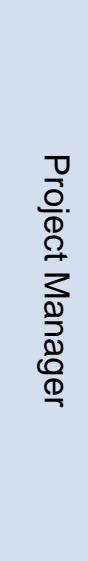 & 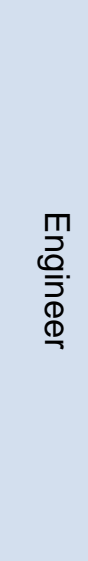 & 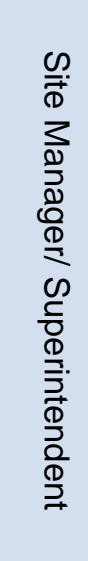 & 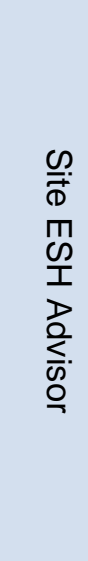 & 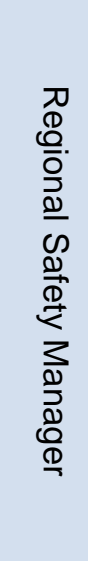 & 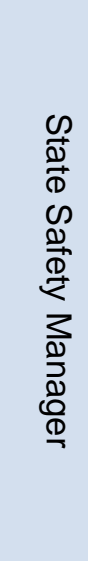 & 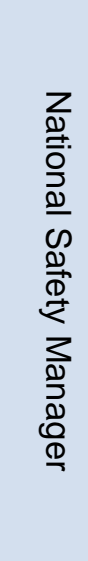 & 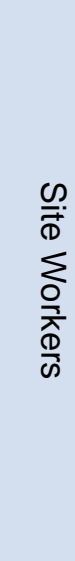 \\
\hline 1 & Safety auditing & P4 & P4 & P4 & P4 & P3 & P3 & P4 & P4 & P4 & P4 & P2 \\
\hline 2 & $\begin{array}{l}\text { Managing Environmental Aspects, Impacts and } \\
\text { OHS hazards }\end{array}$ & $\mathrm{P} 4$ & $\mathrm{P} 4$ & $\mathrm{P} 4$ & $\mathrm{P} 4$ & P3 & P2 & P3 & P3 & $\mathrm{P} 4$ & $\mathrm{P} 4$ & P1 \\
\hline 3 & Project Risk Management & $\mathrm{P} 4$ & P4 & $\mathrm{P} 4$ & P4 & P3 & & P3 & P3 & & & \\
\hline 4 & Safety Recognition and Reward & P4 & & P3 & & & P4 & P3 & P4 & $\mathrm{P} 4$ & P4 & \\
\hline 5 & Safety/Environmental Reporting & & & P3 & $\mathrm{P} 4$ & P3 & P3 & $\mathrm{P} 4$ & & & & \\
\hline 6 & Monitoring Contractors/ Subcontractors & & & P3 & & P4 & P4 & & & & & P1 \\
\hline 7 & Communication & $\mathrm{P} 4$ & P4 & P3 & P4 & P4 & P4 & P3 & P3 & P3 & P4 & $\mathrm{P} 1$ \\
\hline 8 & $\begin{array}{l}\text { OHS Regulatory and Management System } \\
\text { Planning }\end{array}$ & & $\mathrm{P} 4$ & P2 & $\mathrm{P} 4$ & $\mathrm{P} 2$ & P3 & P3 & P2 & P3 & P4 & $\mathrm{P} 1$ \\
\hline
\end{tabular}

Table 9 Mapping proficiency levels to different construction industry jobs 


\section{Assessment}

This section illustrates the manner in which performance ratings can be given to assess sustainability competencies. Typically, most organisations adopt a 5 point rating scale as shown in Table 10. Consider a site worker taking on the competency safety auditing. The targeted proficiency level for safety auditing is P2 for a site worker. There are four likely scenarios here.

\begin{tabular}{|c|c|}
\hline Rating & Description \\
\hline 1 & Poor \\
\hline 2 & Needs improvement \\
\hline 3 & Average \\
\hline 4 & Very good \\
\hline 5 & Excellent \\
\hline
\end{tabular}

Table 10 Performance ratings

Scenario 1: During the performance management process, if the site worker was rated at P1 (which is one level below the targeted P2 proficiency level) only one sublevel is introduced for the competency assessment. The assessor will be asked to select a 'pessimistic' sublevel -since the site worker has failed to master the competency at a P2 proficiency level and is automatically given a rating 1 .

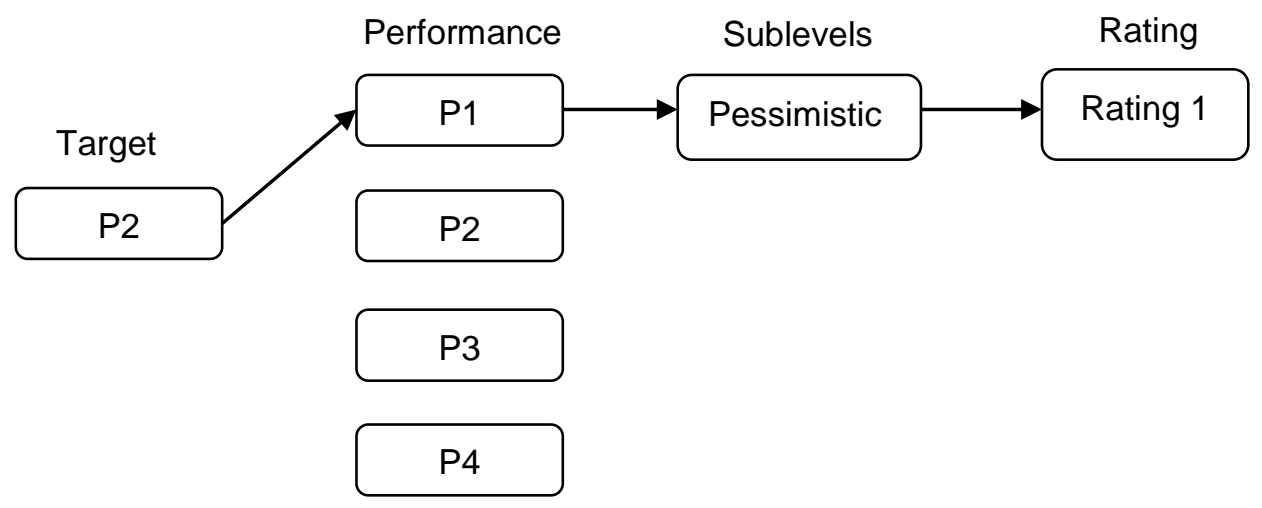

Figure 1 Scenario 1

Scenario 2: During the performance management process, if the site worker was rated at P2 (which is same as the targeted P2 proficiency level) two sublevels are further introduced to provide more nuance to the competency assessment. The assessor will be asked to select either 'most likely' - if the site worker is deemed to have demonstrated full P2 proficiency level or 'pessimistic' - if the site worker has demonstrated his competency at a borderline P2 proficiency level. Depending on the assessor's selection of the sublevels a final performance rating of either 2 or 3 is given.

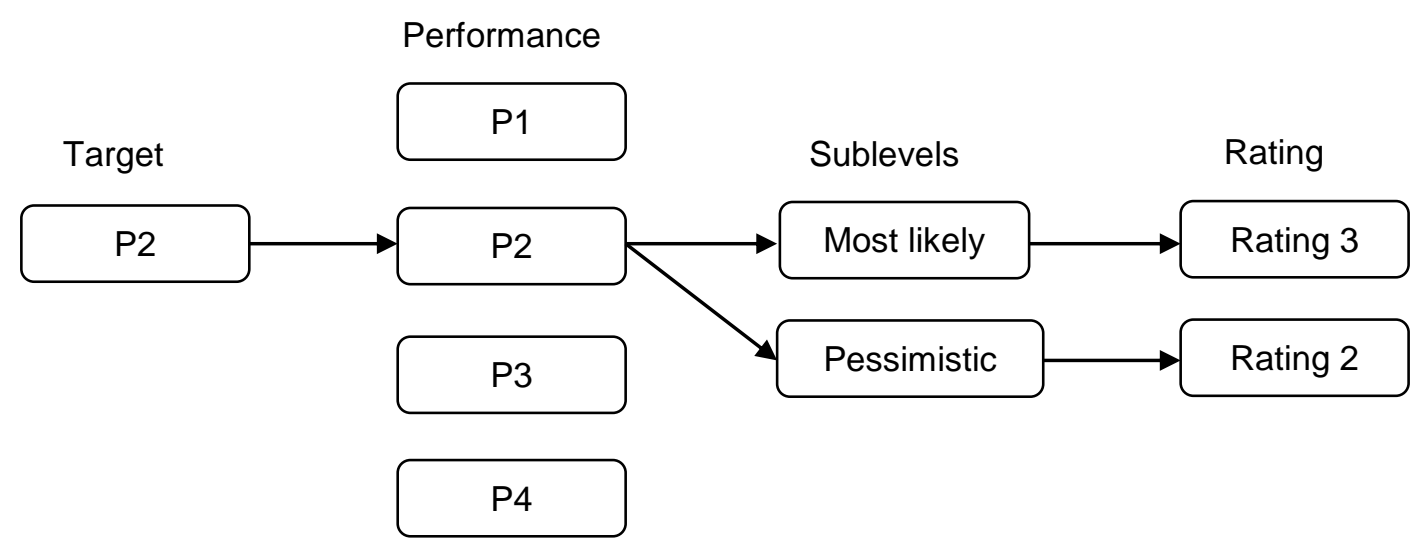

Figure 2 Scenario 2

Siew, R Y J (2014) 'Human resource management in the construction industry - Sustainability competencies', Australasian Journal of Construction Economics and Building, 14 (2) 87-103 
Scenario 3: During the performance management process, if the site worker was rated at P3 (which is one proficiency level above the targeted P2 proficiency level) two sublevels are further introduced to provide more nuance to the competency assessment. The assessor will be asked to select either 'most likely' - if the site worker is deemed to have demonstrated full P3 proficiency level or 'optimistic'- if the site worker has demonstrated his competency at a level slightly higher than a P2 proficiency level but insufficient to achieve a P3 level. Depending on the assessor's selection of the sublevels a final performance rating of either 4 or 5 is given.

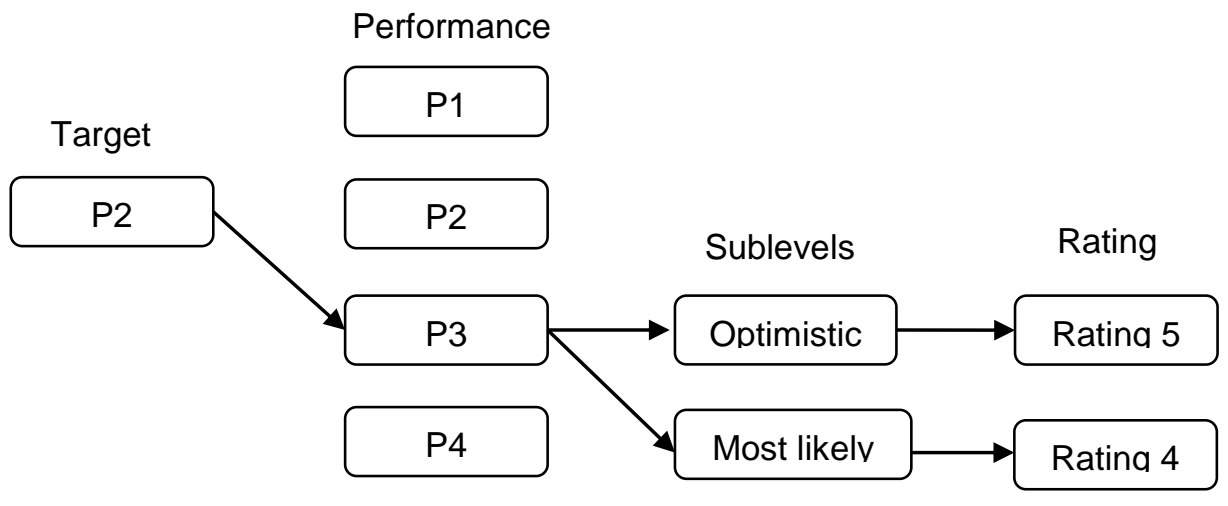

Figure 3 Scenario 3

Scenario 4: During the performance management process, if the site worker was rated at P4 (which is two levels above the targeted P2 proficiency level) only one sublevel is introduced for the competency assessment. The assessor will be asked to select an 'optimistic' sublevel - since the site worker has demonstrated mastery of a competency above and beyond what is expected at a P2 proficiency level and is automatically given a rating 5 .

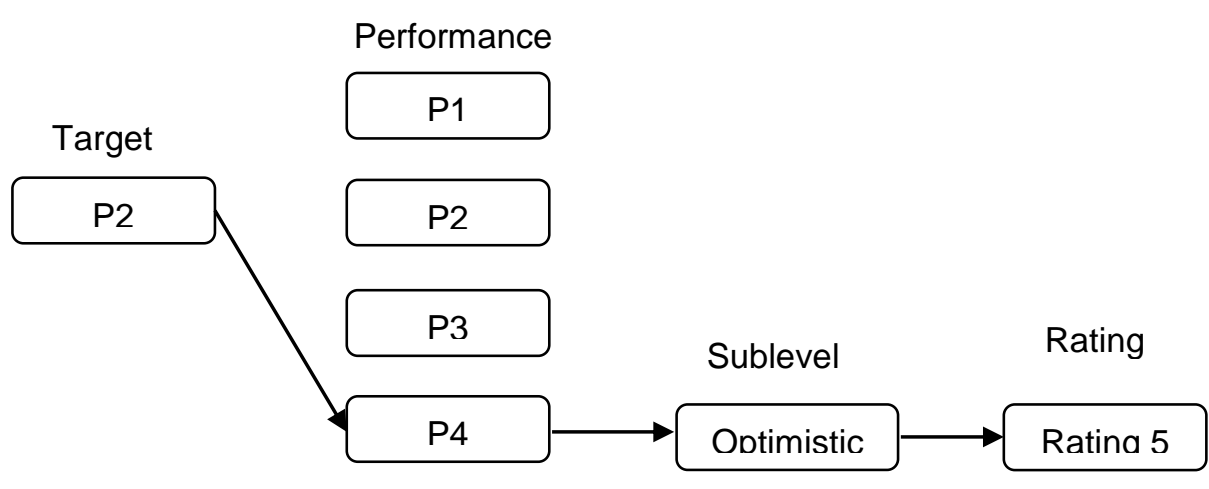

Figure 4 Scenario 4

\section{Conclusion}

There is already a great deal of academic literature dealing with environmental sustainability. Yet, the role of human resource management towards the attainment of sustainable development is still an underdeveloped area of research. This paper makes an original contribution by proposing a sustainability competency framework applicable to the construction industry. The framework consists of a competency dictionary (eight competencies differentiated at four proficiency levels) and suggestions as to how these competencies can be measured. In addition, the proficiency levels required for different jobs within the construction industry are also mapped. 
Future research could possibly look into expanding the sustainability competency framework into other industries apart from construction. The number of participants in a working group can also be increased to further validate the proficiency levels which have been mapped to construction related jobs as shown in Table 9. Based on the recommendation in section 5, HR practitioners may wish to automate the competency assessment through an online platform.

\section{References}

Bevan, S. and Thompson, M. 1992, An Overview of Policy and Practice. Performance Management in the UK: An Analysis of the Issues, Institute of Personnel Management, London.

Bratton, J. and Gold, J. 2003, Human Resource Management Theory and Practice $3^{\text {rd }}$ Edition, Palgrave Macmillan, UK.

Centre for International Economics Canberra and Sydney 2007, 'Embodied carbon metrics will avoid higher than desired carbon content and additional costs', London, viewed 24 March 2012, <http://www.davislangdon.com/ANZ/Sectors/Sustainability/ECM/>

CRC Construction Innovation 2004, 'Construction 2020: a vision for Australia's property and construction industry, Australia, viewed 19 March 2012, $<$ http://eprints.qut.edu.au/40762/1/40762.pdf>

Dahl, A. L. 2012, 'Achievements and gaps in indicators for sustainability, Ecological Indicators, 17, 14-19.

Deming, W. E. 1982, Out of the crisis: Quality Productivity and Competitive Position, Cambridge University Press, Cambridge.

Dingsdag, D. P., Biggs, H. C. Sheahan, V. L. and Cipolla, D. J. 2006, 'A construction safety competency framework: improving $\mathrm{OH} \& \mathrm{~S}$ performance by creating and maintaining a safety culture', CRC for Construction Innovation, Brisbane, Queensland.

Druker, J. and White, G. 2002, 'Misunderstood and undervalued? Personnel management in construction', Human Resource Management Journal, 5 (3), 77-91.

Dunphy, D. and Griffiths, A. 1998, The Sustainable Corporation, Allen Unwin, Sydney.

Harmon, J., Fairfield, K. D. and Wirtenberg, J. 2010, 'Missing an opportunity: HR leadership and sustainability', People and Strategy, 33 (1), 16-21.

Loosemore, D., Dainty, A. and Lingard, H. 2003, Human Resource Management in Construction Projects: Strategic and Operational Approaches, Spon Press, New York.

McGregor, D. 1960, The Human Side of Enterprise: McGraw-Hill, New York.

Newell, S. and Shackleton, V. 2000, Recruitment and Selection, Blackwell Publishers Ltd, UK.

Spooner, K. and Kaine, S. 2010, 'Defining sustainability and human resource management', International Employment Relations Review, 16 (2), 70-81.

Storey, J. 1992, Developments in the Management of Human Resources, Blackwell Publishers Ltd, Oxford, UK.

Wilkinson, A., Hill, M. and Gollan, P. 2001, 'The sustainability debate', International Journal of Operations and Production Management, 21 (12), 1492-1502.

Wirtenberg, J., Harmon, J., Russell, W. G. and Fairfield, K. D. 2007, 'HR's role in building a sustainable enterprise: insights from some of the world's best companies', Human Resource Planning, 30 (1), 1-13. 


\section{CRC Construction Innovation Safety Management Tasks (SMTs)}

SMT 1 Carry out project risk assessments

SMT 6 Carry out workplace/task hazard identification, risk assessments and controls

SMT 13 Plan and deliver toolbox talks

SMT $16 \quad$ Consult on and resolve OH\&S issues

SMT 18 Challenge unsafe behaviour/attitude at any level when encountered

SMT 19 Make site visits where a site worker is spoken to directly about OH\&S

SMT 20 Recognise and reward people who have positively impacted on $\mathrm{OH} \& \mathrm{~S}$

SMT 22 Carry out formal incident investigations

SMT $24 \quad$ Carry out formal inspections of workplace and work tasks

SMT 25 Research and prepare reports on OH\&S issues, performance and improvement strategies

SMT $26 \quad$ Monitor sub-contractor activities

SMT $29 \quad$ Understand and apply general legislative OH\&S requirements

SMT $36 \quad$ Work with staff to solve safety problems 